\title{
The rheological behavior of a pseudo-oil-based mud formulated with Hura crepitans plant oil as base fluid
}

\author{
C. Y. Onuh ${ }^{1}$ - A. Dosunmu ${ }^{2}$ P. A. L. Anawe ${ }^{1}$ - E. E. Okoro ${ }^{1}$ ' K. C. Igwilo ${ }^{1}$ - A. B. Ehinmowo ${ }^{3}$
}

Received: 4 January 2019 / Accepted: 25 June 2019 / Published online: 1 July 2019

(c) The Author(s) 2019

\begin{abstract}
The need to prevent our environment from deterioration caused by toxic waste from drilling mud is a prime objective to the oil and gas industry. The exploration of non-edible plant oil for potential base oil in formulating drilling mud is progressing due to the environmentally friendly nature. This research work involves using a commercial synthetic oil from the oil industry and Hura crepitans oil. This oil samples were used as a base fluid in preparing the mud from which the rheological properties were analyzed. Chemical oil extraction method using soxhlet apparatus was used to extract the oil from H. crepitans seeds; it was then distilled to remove the solvent. The mud samples were formulated with 7 and $9 \mathrm{~g}$ concentrations of the viscosifier, and properties were measured at 113 and $158^{\circ} \mathrm{F}$. It was then aged for $16 \mathrm{~h}$ at $240{ }^{\circ} \mathrm{F}$, and mud properties were measured before and after hot rolling for comparison. Different rheological models were used to describe the experimental data. The physical properties of the synthetic oil and H. crepitans oil reveal a flash point of 213.8 and $399.2^{\circ} \mathrm{F}$, fire point of 226.4 and $500^{\circ} \mathrm{F}$, viscosity index of 297 and 207, specific gravity/density of 805 and 907, respectively. The mud properties of the synthetic oil-based mud had a better emulsion stability, lower plastic viscosity, higher yield point values, and lower gel strength than the $H$. crepitans oil-based mud. The rheological properties of synthetic and $H$. crepitans oil-based mud increase and decrease, respectively, after hot rolling. The optimal concentration of viscosifier was $7 \mathrm{~g}$ to have maintained the API acceptable range for the rheological properties. Based on the $R^{2}$ values, RMSE values, and the fitted plots, Herschel-Bulkley had a better description of the experimental data.
\end{abstract}

Keywords Synthetic oil-based mud $\cdot$ Hura crepitans oil-based mud $\cdot$ Shear stress $\cdot$ Shear rate $\cdot$ Rheological properties Aging

C. Y. Onuh

charles.onuh@covenantuniversity.edu.ng

A. Dosunmu

adewale.dosunmu@gmail.com

P. A. L. Anawe

paul.anawe@covenantuniversity.edu.ng

E. E. Okoro

emeka.okoro@covenantnuiversity.edu.ng

K. C. Igwilo

kevin.igwilo@covenantuniversity.edu.ng

A. B. Ehinmowo

aehinmowo@unilag.edu.ng

1 Department of Petroleum Engineering, Covenant University, Ota, Nigeria

2 Department of Petroleum and Gas Engineering, University of Port Harcourt, Port Harcourt, Nigeria

3 University of Lagos, Lagos, Nigeria

\section{Introduction}

Petroleum-based fluids used for the formulation of drilling fluids have relatively significant amount of aromatics and n-olefins; these compounds are toxic and harmful to the environment (Dardir et al. 2014). Thus, the oil and gas industry has been presented with a variant form of oil-based muds called synthetic and/or pseudo-oil-based muds. The initial cost of forming a synthetic oil-based mud compared with oil-based muds (OBMs) can be doubled (Growcock and Patel 2011); but the cost of treatment, transportation, and disposal after drilling operation can be higher for OBMs when compared with the synthetic-based muds (SBMs). Using SBMs can reduce a well drilling time by $35-55 \%$ which will in turn reduce the cost of the well. According to (Amorin et al. 2015b), $n$-alkane SBM was used in drilling over 130 wells in Central Graben area of the UK. The drilling phase of the project was relatively problem free,

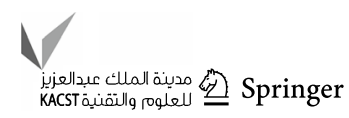


thus resulting in significant operational cost savings with completed high-productive horizontal wells. Amorin et al. (2015a) observed that the average cost savings in the percentage for plant oils as base fluids over commercial synthetic-based fluids, for onshore and offshore were $56.30 \%$ and $48.32 \%$, respectively. Thus, plant oil-based fluids are more economical compared to some synthesized-based fluids.

It has been discovered that vegetable oil-based drilling muds exhibit superior rheological properties, and these properties can be compared favorably with the petroleum-based drilling muds (Agwu et al. 2015; Dosunmu and Ogunride 2010). The potential geothermal stability of these plant oils can be enhanced naturally. According to (Amorin et al. 2015b), a combination of antioxidants added to their base oil improved the stability of the oil samples when compared to using individual antioxidants. They identified some of these natural potential antioxidants as extracts from red onion skin, citric acid and so on. The use of these antioxidants is to preserve the unsaturated fatty acids which will improve the thermal stability of the plant oils. Atabani et al. (2013) confirmed the relevant properties of vegetable oil being biodegradable, renewable, and non-toxic. It is also less volatile due to its high molecular weight of tri-glycerol molecule, minimal viscosity change with temperature, superior corrosion properties due to its affinity with metal, non-flammable property due to the high flash point, good lubrication property based on their polarity, unique solvency property as a result of the solubility with other oils (Salih et al. 2011). Over the last decade, the attention of researchers has been drawn to the use of non-edible plant oils in drilling mud formulation. The significant nature is in the no-competition with the demands of edible oil for food source. The use of edible vegetable oils or the first generation feedstock has been a concern, and there are on-going debates on the diversion of some resources of food crops to biofuel raw materials (Haines and Gerpen 2014; Searchinger and Heimlich 2015). Non-edible plant can be cultivated on low-fertility soil and poor wastelands that are not suitable for food crops, and are a good potential of restoring degraded lands. Hence, they do not compete with agricultural resources.

In order to achieve proper functionality of the drilling fluids, appropriate drilling fluids must be selected with a proper understanding of the rheological properties. The rheological properties largely determine the efficiency of the mud in hole cleaning, cutting carrying capacity, and transportation to the surface.

\section{Temperature effect on the rheological behavior of drilling fluid}

Drilling fluid behavior differs under different temperature and pressure conditions, and this accounts for why one single rheological model is not good enough to describe their flow behavior: fluid in general and either Newtonian or nonNewtonian in behavior. Mozaffari et al. 2015 observed Newtonian fluid behavior for bitumen solution which maintains constant viscosity as the shear stress and shear rate changes. Most fluids are non-Newtonian in behavior, and they do not conform to a single model due to their complexities. NonNewtonian fluid does not exhibit constant viscosity, that is, the measure of the fluid ability to resist deformation by shear stress is dependent on the shear rate. This implies that the viscosity of the fluid changes as the shear rate changes. The increase or decrease in the rheological properties (plastic viscosity, gel strength, and yield point) can be due to the reaction between the fluid molecules under the influence of temperature. The rheological properties of formulated synthetic ester oil-based and industry synthetic oil-based mud were measured at low temperatures of $23^{\circ} \mathrm{K}$ to $68^{\circ} \mathrm{K}$ (Fadairo et al. 2017). Decrease in the dial readings and in the rheological properties was observed with a decrease in the temperature in the ethyl biodiesel and industrial synthetic oil-based mud. Anawe et al. (2014) measured the effect of temperature on the rheological properties of Jatropha curcas oil, groundnut oil, and diesel oil in formulating drilling mud. It was discovered that the rheological properties of all the mud samples decrease as the temperature reduces from $140^{\circ} \mathrm{K}$ to $176^{\circ} \mathrm{K}$ and $212^{\circ} \mathrm{K}$. High-temperature highpressure effects on rheological properties of oil and waterbased mud beyond $212^{\circ} \mathrm{K}$ were also examined by Amani 2012. The rheological properties were compared at temperatures from $100{ }^{\circ} \mathrm{F}$ to $600{ }^{\circ} \mathrm{F}$ and pressure from 5000 to 25 , $000 \mathrm{psi}$. It was discovered that the oil-based mud possesses high dial readings than the water-based mud. The complex drilling fluid behavior was seen when the dial readings and rheological properties of the oil-based mud decreased when temperature increased from $100^{\circ} \mathrm{F}$ to $400{ }^{\circ} \mathrm{F}$, and increased beyond the temperature of $400{ }^{\circ} \mathrm{F}$ to $600{ }^{\circ} \mathrm{F}$. Ibeh (2007) also investigated the impacts of ultra-high temperatures and pressures on the rheological properties of the mud prepared with diesel oil and mineral oil. There was a uniform exponential decline in the rheological properties of the mud up until $450{ }^{\circ} \mathrm{F}$. Beyond this temperature, a slight increase was observed which stopped at $500{ }^{\circ} \mathrm{F}$ and then declined to $600^{\circ} \mathrm{F}$.

Dardir and Hafiz (2013) compared the rheological properties of formulated ester-based mud and that of a field ester-based mud at $77^{\circ} \mathrm{F}$ to $212^{\circ} \mathrm{F}$, and under aging conditions of $16 \mathrm{~h}$ and temperature of $350{ }^{\circ} \mathrm{F}$. The rheological properties of the formulated ester and field ester-based mud decrease with the increase in the temperature from $77^{\circ} \mathrm{F}$ to $212^{\circ} \mathrm{F}$. However, the formulated ester-based mud had a slight decrease compared to the field ester-based mud. Under the aging conditions, the rheological properties decrease as aging time increases from 0 to $16 \mathrm{~h}$. 


\section{Methodology}

\section{Extraction procedure}

Hura crepitans oil was extracted from the grinded seed sample using a soxhlet extractor. Sixty grams of the grinded plant seed [Fig. 1(right)] was poured into the thimble of the soxhlet extractor, and $250 \mathrm{ml}$ of N-Hexane solvent into the $500 \mathrm{ml}$ round-bottom flask of the extractor. The soxhlet apparatus was then mounted on a heating mantle at $153^{\circ} \mathrm{F}$ which is equivalent to the boiling temperature of hexane $\left(67{ }^{\circ} \mathrm{C}\right)$; it was then allowed to reflux for roughly $2 \mathrm{~h}$. The extracted oil was then filtered to get rid of existing impurities and vaporized with a distillation evaporator set up to separate the solvent from the oil. This process was repeated until the desired quantity of oil was achieved.

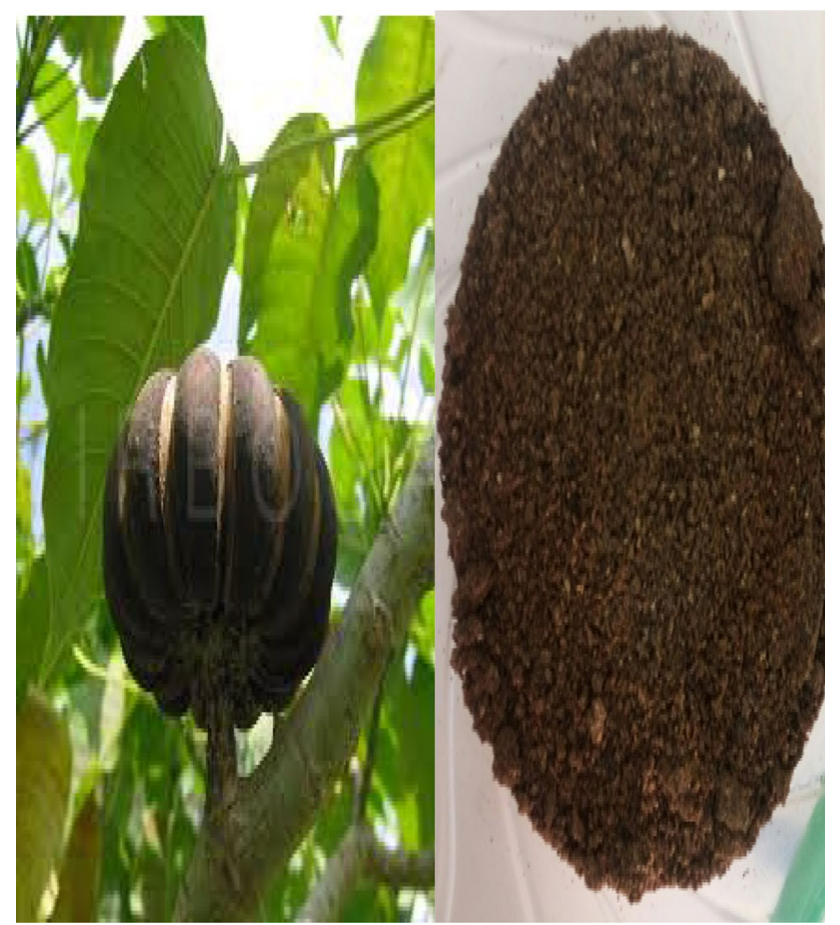

Fig. 1 Seed of Hura crepitans (Left) and its grinded form (Right)

\section{Formulation of the mud samples}

The oil-based mud was formulated using a commercial synthetic oil obtained from the industry, and also formulated using oil extracted from the seed of Hura crepitans. The additives used in preparing the Hura crepitans oil-based mud (HCOBM) and synthetic oil-based mud (SOBM) are shown in Table 1 . The mud mixing was carried out in the Hamilton beach mixing machine to ensure homogeneity; the mixing order starts from 1 to 5 (See Table 1) at oil/water ratio of 70:30. The concentration of the viscosifier was varied in 7 and $9 \mathrm{~g}$ to measure the effect of the viscosifier on the rheological properties. The mud density and emulsion stability (ES) were measured using the mud balance and emulsion stability meter, respectively. The viscometer calibrated in revolution per minute (RPM) was used to measure the rheological properties of the mud. System was allowed to reach equilibrium and measurement taken twice to minimise errors. The rheological properties (plastic viscosity, yield point, and gel strength) were calculated from the dial deflections. Conversion factor was used to convert the dial readings to shear stress/shear rate obtained, too. The gel strength at $10 \mathrm{~s}$ and $10 \mathrm{~min}$ was determined from the viscometer.

\section{Aging}

The SOBM and HCOBM containing $7 \mathrm{~g}$ and $9 \mathrm{~g}$ of the viscosifier were placed separately in a high-pressured aging cell, and into the dynamic rolling machine for $16 \mathrm{~h}$ at $240^{\circ} \mathrm{F}$. The purpose of aging is to simulate downhole conditions. After hot rolling (AHR) of the mud samples, the dial readings, yield point, gel strength at $10 \mathrm{~min}$ and $10 \mathrm{~s}$, and plastic viscosity were measured and compared to mud conditions before hot rolling (BHR).

\section{Rheological modeling}

The following rheological models were used in describing the experimental rheological data for the SOBM and HCOBM containing 7 and $9 \mathrm{~g}$ viscosifier. The models used are as follows:
Table 1 Composition of synthetic and Hura crepitans oil-based mud

\begin{tabular}{llllll}
\hline Additives & Amount & Order & Additives & Amount & Order \\
\hline Hura crepitans oil $(\mathrm{ml})$ & 245 & 1 & Synthetic oil $(\mathrm{ml})$ & 245 & 1 \\
Omni-tech emulsifier $(\mathrm{ml})$ & 20 & 2 & Omni-tech emulsifier $(\mathrm{ml})$ & 20 & 2 \\
Lime $(\mathrm{g})$ & 3 & 3 & Lime $(\mathrm{g})$ & 3 & 3 \\
De-ionized water $(\mathrm{ml})$ & 105 & 4 & De-ionized water $(\mathrm{ml})$ & 105 & 4 \\
Viscosifier (carbogel) $(\mathrm{g})$ & 7 and 9 & 5 & Viscosifier (carbogel) $(\mathrm{g})$ & 7 and 9 & 5 \\
Barite $(\mathrm{g})$ & 40 & 6 & Barite $(\mathrm{g})$ & 40 & 6 \\
\hline
\end{tabular}




\section{Herschel-Buckley rheological model}

The three-parameter model relates the shear stress to shear rate as represented mathematically in the equation as follows:

$\tau=\tau_{01}+K_{1} *(\dot{\gamma})^{n}$

where the $\tau, \tau_{01}, \dot{\gamma}, K_{1}, n$ represents the shear stress, yield stress, shear rate, correction parameter, and flow behavior index, respectively. Flow constant is considered as shear thinning when $n<1$ and shear thickening when $n>1$. Equation (1) reduces to a Newtonian fluid when $n=1$ and $\tau_{01}=0$

\section{Hyperbolic rheological model}

The shear stress-shear rate relationship model defines the hyperbolic model as follows.

$\tau=\tau_{02}+\frac{\dot{\gamma}}{A+B \dot{\gamma}}$

where $\tau_{02}$ is the yield stress, $A$ and $B$ are the model parameters.

\section{Sisco rheological model}

The Sisco model relates the shear stress-shear rate relationship using three parameters

$\tau=K_{2} \dot{\gamma}+K_{3}(\dot{\gamma})^{m}$

where $K_{2}, K_{3}$, and $m$ are the coefficient of viscosity, consistency coefficient, and fluid flow index, respectively. For a pseudoplastic (shear thinning) fluid, $m<1$. For a dilatant (shear thickening) fluid, $m>1 . m=1$ for a Newtonian fluid.

\section{Casson rheological model}

Two parameters are used to relate the shear stress-shear rate

$\tau^{1 / 2}=\tau_{03}^{1 / 2}+K_{4}^{1 / 2}(\dot{\gamma})^{1 / 2}$

where $k_{4}$ and $\tau_{03}$ are model constant and yield stress, respectively.

\section{Accuracy of the rheological models}

The accuracy of the models used in describing the experimental data was quantified using the root mean square error (RMSE), the coefficient of determination $(R)^{2}$, and the fitted plots. The RMSE and $R^{2}$ expression are shown as follows.

$\operatorname{RMSE}=\sqrt{\frac{\sum_{i=1}^{n}\left(y_{i}-x_{i}\right)^{2}}{N}}$
Table 2 Properties of the oil samples

\begin{tabular}{llll}
\hline Oil properties & SO & HCO & API \\
\hline Flash point $\left({ }^{\circ} \mathrm{C}\right)$ & 213.8 & 399.2 & $\geq 150.8$ \\
Fire point $\left({ }^{\circ} \mathrm{C}\right)$ & 226.4 & 500 & $\geq 199.4$ \\
Density $(\mathrm{kg} / \mathrm{m} 3)$ & 805 & 907 & $805-820$ \\
Kin. visc @ $40{ }^{\circ} \mathrm{C}(\mathrm{cp})$ & 4.27 & 14.70 & \\
Kin. visc @ $100{ }^{\circ} \mathrm{C}(\mathrm{cp})$ & 4.04 & 7.55 & \\
Viscosity Index $(\mathrm{VI})$ & 297 & 207 & \\
\hline
\end{tabular}

$R^{2}=\left[\frac{\sum_{i}\left(x_{i}-\bar{x}\right)\left(y_{i}-\bar{y}\right)}{\sqrt{\sum_{i}\left(x_{i}-\bar{x}\right)^{2}} \sqrt{\sum_{i}\left(y_{i}-\bar{y}\right)^{2}}}\right]^{2}$

\section{Results and discussion}

\section{Oil yield of Hura crepitans}

Weight of seed sample used $=60 \mathrm{~g}$

Weight of oil recovered $=22 \mathrm{~g}$

Oil yield $=\left(\frac{22}{60}\right) * 100=37 \%$

\section{Synthetic and Hura crepitans oil}

Table 2 shows the properties of the synthetic oil (SO) and Hura crepitans oil (HCO) measured. The flash and fire point of the oil samples are within the range of the API standard. It can also be seen that the flash and fire point of $\mathrm{HCO}$ are higher than those of the synthetic oil, which implies $\mathrm{HCO}$

Table 3 Physical properties of SOBM prepared at different concentrations of the viscosifier

\begin{tabular}{|c|c|c|c|c|}
\hline \multirow[t]{2}{*}{ Properties } & \multicolumn{2}{|c|}{$\begin{array}{l}\text { Dial reading @ } \\
158^{\circ} \mathrm{F}\end{array}$} & \multicolumn{2}{|c|}{$\begin{array}{l}\text { Dial reading } \\
\text { @ } 113^{\circ} \mathrm{F}\end{array}$} \\
\hline & $7 \mathrm{~g}$ & $9 \mathrm{~g}$ & $7 \mathrm{~g}$ & $9 \mathrm{~g}$ \\
\hline Mud density (ppg) & 8.39 & 8.35 & 8.1 & 8.3 \\
\hline Electrical stability (ES) & 554 & 695 & 423 & 678 \\
\hline
\end{tabular}

Table 4 Physical properties of HCOBM at different concentrations of the viscosifier

\begin{tabular}{|c|c|c|c|c|}
\hline \multirow[t]{2}{*}{ Properties } & \multicolumn{2}{|c|}{$\begin{array}{l}\text { Dial reading @ } \\
158^{\circ} \mathrm{F}\end{array}$} & \multicolumn{2}{|c|}{$\begin{array}{l}\text { Dial reading @ } \\
113^{\circ} \mathrm{F}\end{array}$} \\
\hline & $7 \mathrm{~g}$ & $9 \mathrm{~g}$ & $7 \mathrm{~g}$ & $9 \mathrm{~g}$ \\
\hline Mud density (ppg) & 7.4 & 7.7 & 8.4 & 8.3 \\
\hline Electrical stability (ES) & 532 & 552 & 530 & 592 \\
\hline
\end{tabular}


Fig. 2 The shear stress-shear rate of synthetic oil-based mud at $7 \mathrm{~g}, 9 \mathrm{~g}$ viscosifiers, $113^{\circ} \mathrm{K}$, $158^{\circ} \mathrm{K}$ temperatures

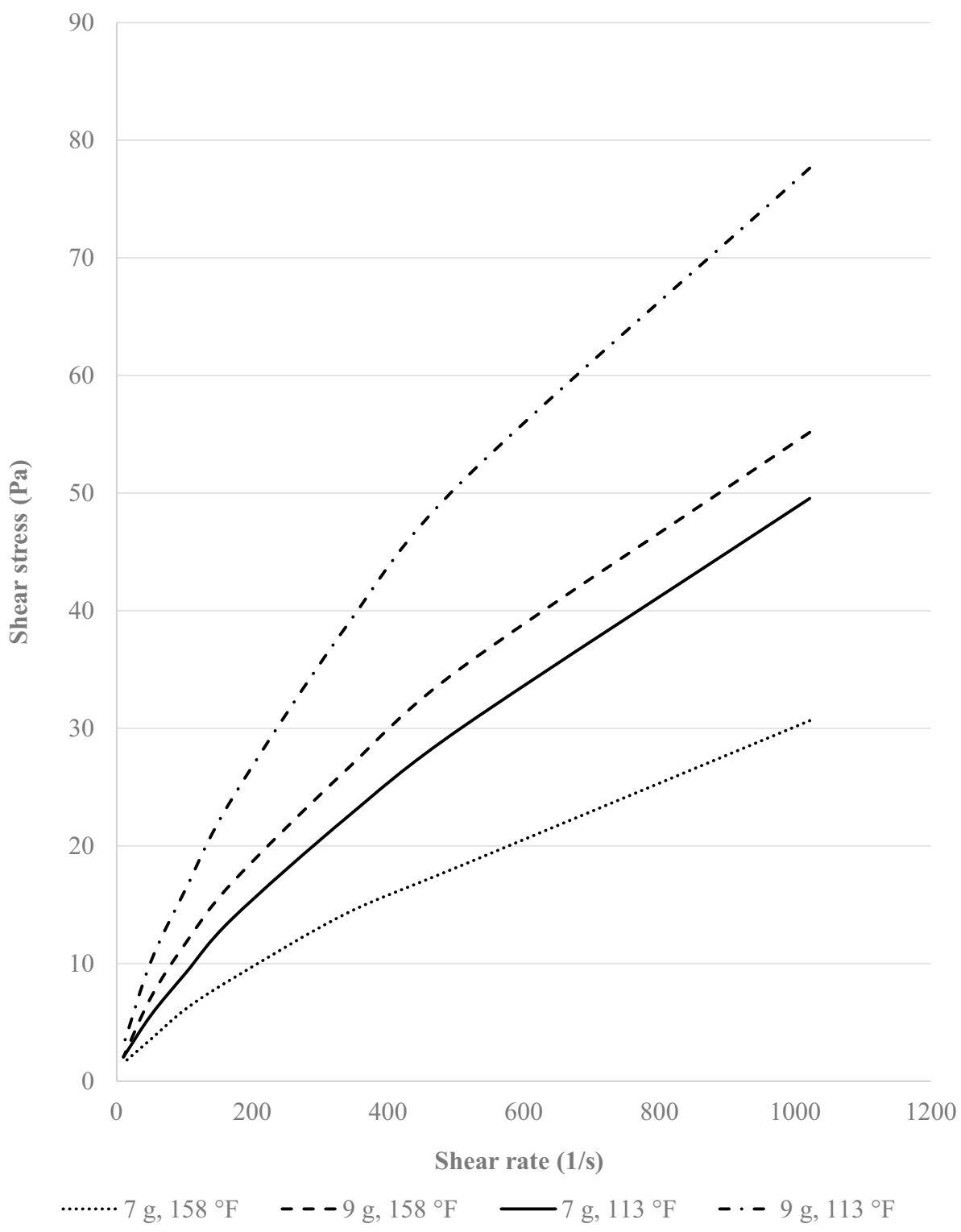

is less volatile than the synthetic oil. The viscosity index determined at $40{ }^{\circ} \mathrm{C}\left(104^{\circ} \mathrm{F}\right)$ and $100^{\circ} \mathrm{C}\left(212^{\circ} \mathrm{F}\right)$ shows that the viscosity of the synthetic oil is higher than that of the HCO. This reveals that the viscosity of the synthetic oil is more thermally stable, i.e., the rate at which it changes with temperature is relatively less. The density of synthetic oil is within the API range, while that of the Hura crepitans oil was not.

\section{Mud properties}

Tables 3 and 4 reveal the properties of the mud prepared with the synthetic oil and Hura crepitans oil, respectively.
The mud properties were measured at different concentrations of the viscosifier (carbogel) and at different temperatures. The mud density decreases with temperature and increases with the concentration of the viscosifier. Emulsion stability is one of the important properties of the oilbased mud; it determines the miscibility and how good the emulsion is. The emulsion stability (ES) increases with the concentration of the viscosifier and fairly increases with the increase in the temperature. The higher the ES value, the more stable is the emulsion. The mud formulated with synthetic oil has higher emulsion stability than that with the plant oil. The mud density of SOBM is averagely higher than that of the HCOBM 
Fig. 3 The shear stress-shear rate of Hura crepitans oil-based mud at $7 \mathrm{~g}, 9 \mathrm{~g}$ viscosifiers and $113^{\circ} \mathrm{K}, 158^{\circ} \mathrm{K}$ temperatures

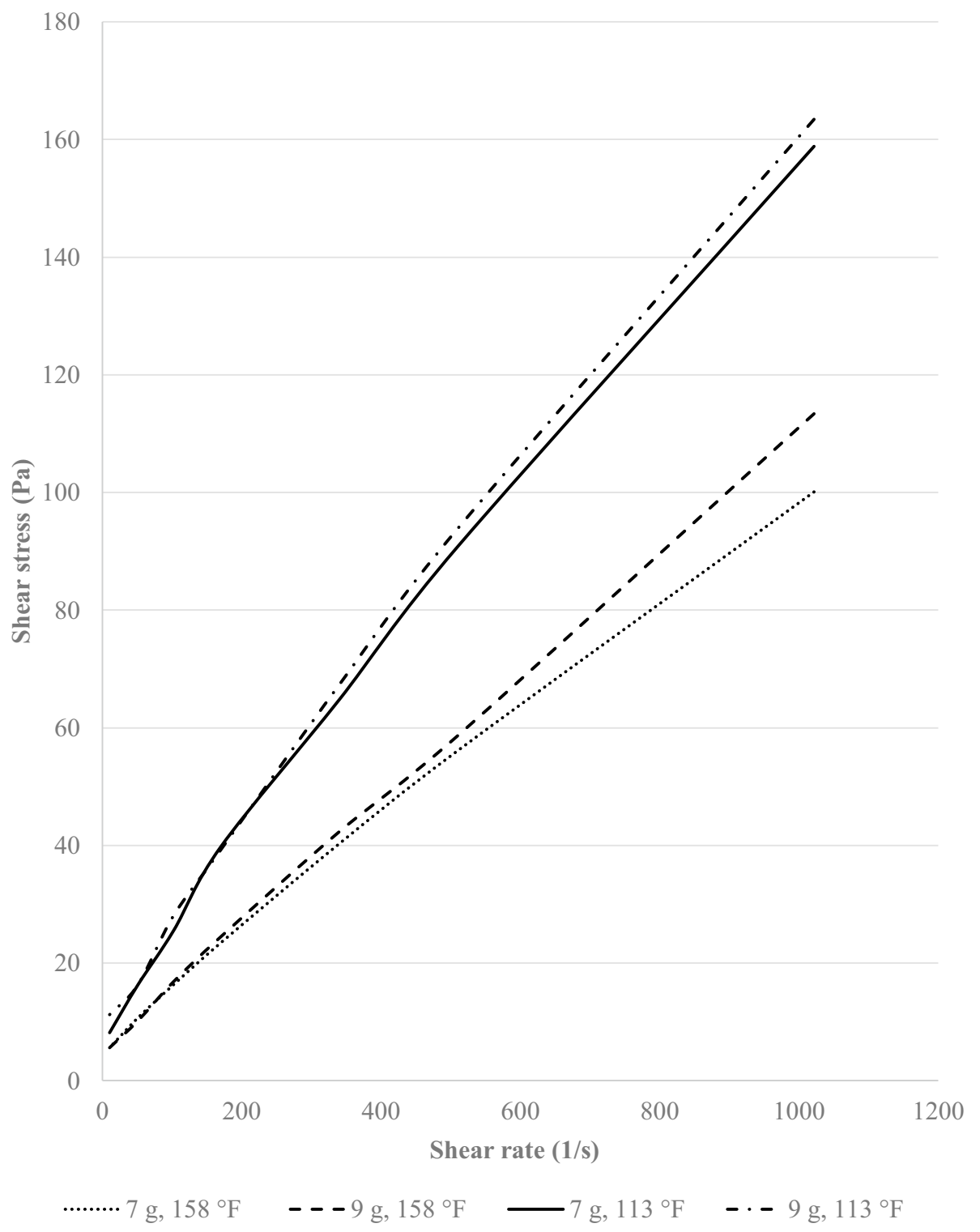

\section{Analyzing the rheological properties of synthetic and Hura crepitans oil-based mud}

i. Effect of temperature and the viscosifier on the shear stress-shear rate of the mud

Figure 2 presents the flow curves of mud samples prepared with the synthetic oil; the effect of the viscosifier at 7 and $9 \mathrm{~g}$ and temperature at 113 and $158^{\circ} \mathrm{F}$ was studied. The yield stress is the crossing point with the $y$-axis, although there was no visible crossing point with the y-axis due to the minimum shear rate $\left(10 \mathrm{~s}^{-1}\right)$. The mud is most shear thinning in the lower shear rate range of $10 s^{-1}$ to about 400 $s^{-1}$ and later increased more linearly; this is possible due to the effect of temperature. The yield stress for the $7 \mathrm{~g}, 113^{\circ} \mathrm{K}$ measurement is higher than that for the $7 \mathrm{~g}, 158^{\circ} \mathrm{K}$ measurement; and likewise the yield stress for the $9 \mathrm{~g}, 113^{\circ} \mathrm{K}$ measurement is more than that for the $9 \mathrm{~g}, 158^{\circ} \mathrm{K}$ measurement. This shows the effect of temperature on the shear stress-shear rate. The shear stress-shear rate relationship was found to be nonlinear; and so, the viscous flow curves exhibit a non-Newtonian flow behavior over a wide range of shear rate. The shear stress increases with the increase in the viscosifier, and this shows the function of the carbogel acting as a viscosifying agent.

Figure 3 presents the flow curves of mud samples prepared with the oil from the plant seed of Hura crepitans; 
Fig. 4 The plastic viscosity of synthetic and Hura crepitans oil-based mud at $7 \mathrm{~g}, 9 \mathrm{~g}$ viscosifiers and $113^{\circ} \mathrm{K}, 158^{\circ} \mathrm{K}$ temperatures

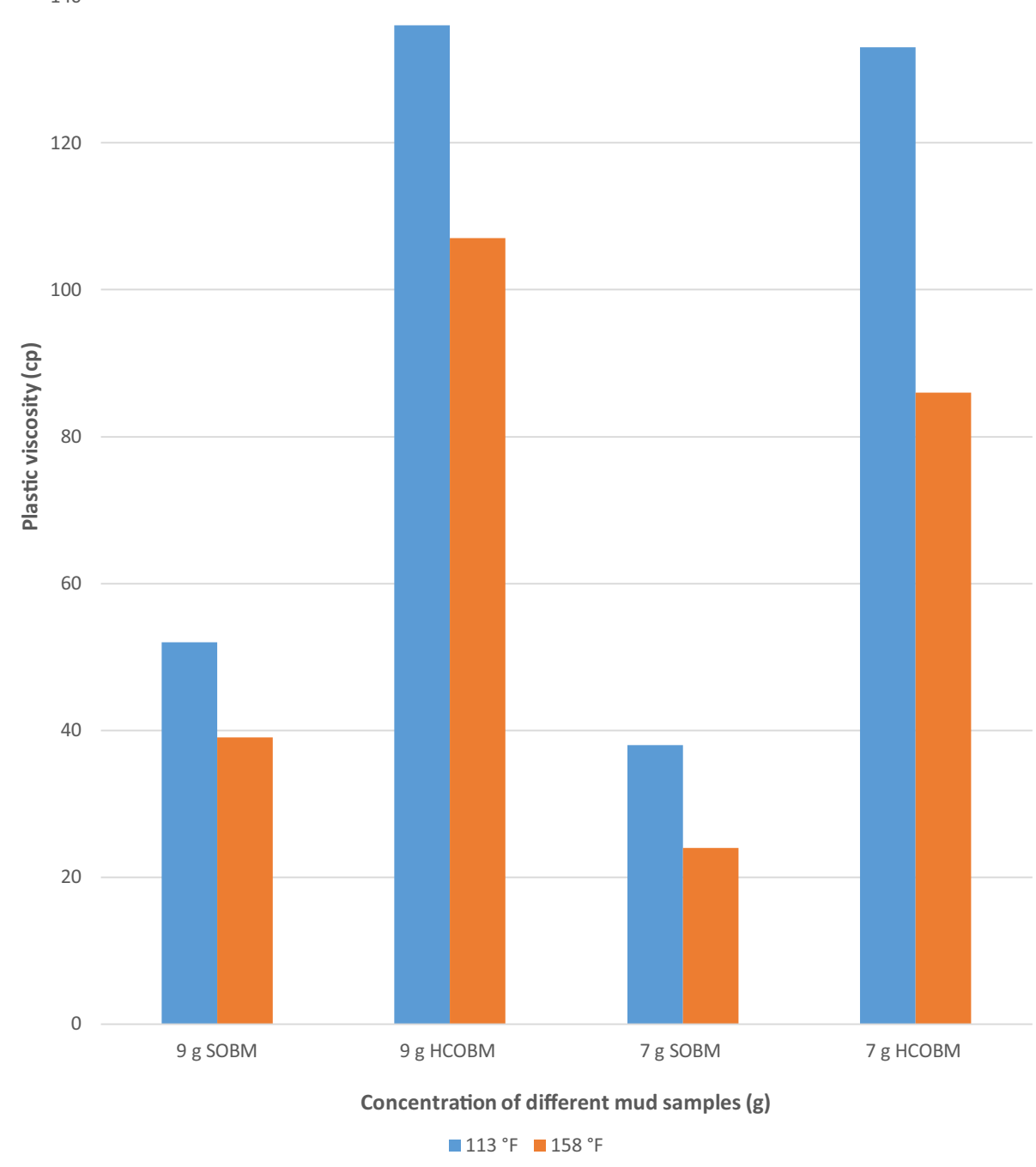

the effect of the viscosifier at 7 and $9 \mathrm{~g}$ and temperature at 113 and $158^{\circ} \mathrm{F}$ was studied. There was no visible crossing point with the $y$-axis because of the minimum shear rate $\left(10 s^{-1}\right)$. The mud shear thinning effect is not visible for the plant oil, and this occurred at a shear rate ranging from 10 $s^{-1}$ to about $200 s^{-1}$ and later increased more linearly; this is as a result of the temperature effect. The viscous flow curves exhibit a synonymous Newtonian flow behavior over a wide range of shear rate due to the linearity of the plot. The shear stress increases with the increase in the viscosifier, and also decreases with the increase in the temperature from $113^{\circ} \mathrm{F}$ to $158^{\circ} \mathrm{F}$; similar occurrence in the shear stress-shear rate profile is also seen in the work of Li et al. (2016). In comparing the shear stress-shear rate between the SOBM and HCOBM, lower profile was observed in the SOBM than in the HCOBM for 7 and $9 \mathrm{~g}$ concentrations of the viscosifier. This was due to the higher viscosity of Hura crepitans oil relative to the commercial synthetic oil.

ii. Effect of temperature and the viscosifier on the plastic viscosity and yield point of the synthetic and Hura crepitans oil-based mud

As shown in Fig. 4, the plastic viscosity values of the HCOBM are significantly higher than those of the SOBM, 
Fig. 5 The yield point of synthetic and Hura crepitans oil-based mud at $7 \mathrm{~g}, 9 \mathrm{~g}$ viscosifiers and $113^{\circ} \mathrm{K}, 158^{\circ} \mathrm{K}$ temperatures

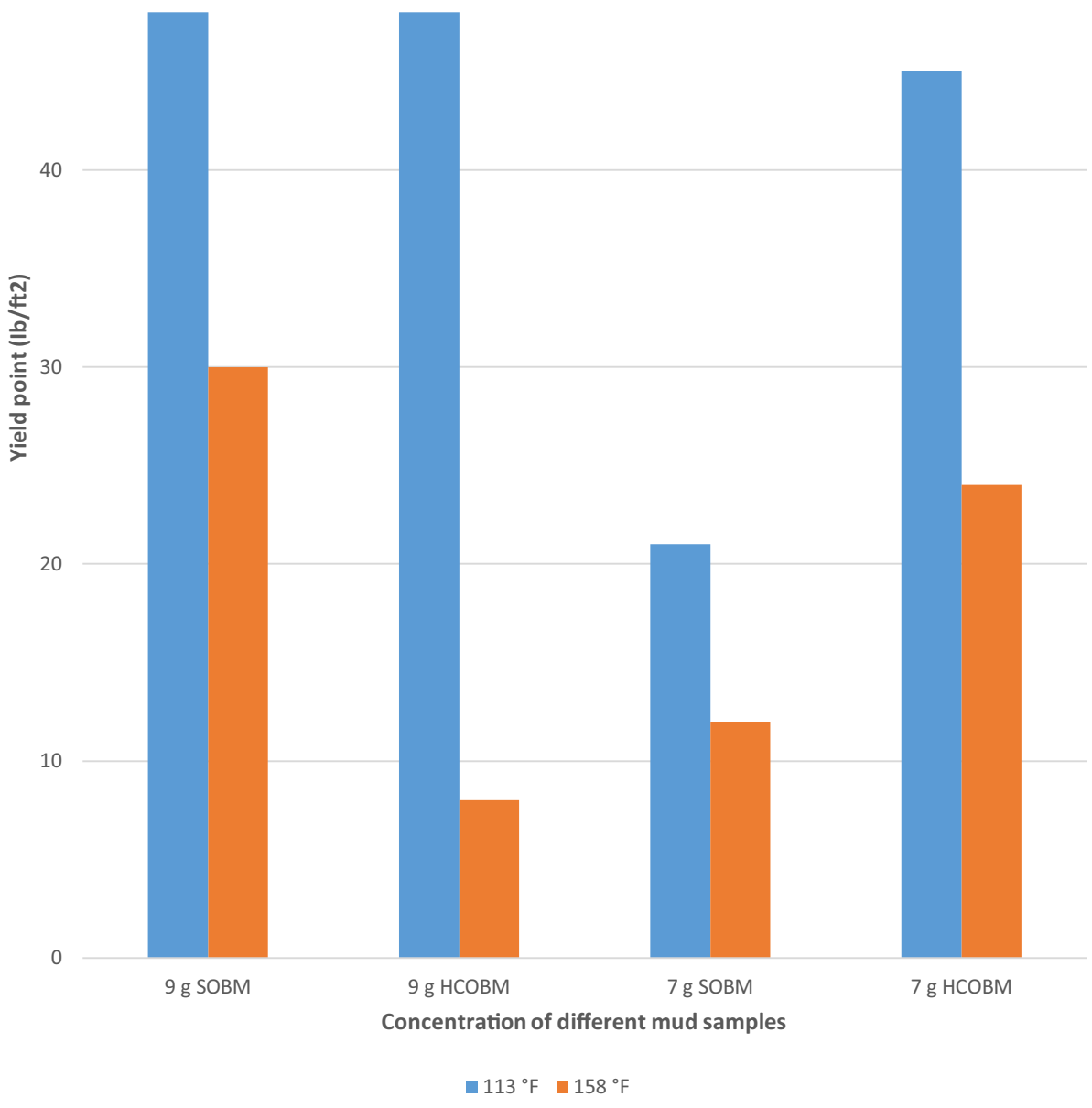

the $9 \mathrm{~g}$ viscosifier of the HCOBM and SOBM is higher than its respective $7 \mathrm{~g}$ mud. The higher the plastic viscosity values, the more viscous the mud which can cause a high resistance to flow. The negative effect of high viscous mud is in the low performance in the transportation of cuttings to the surface. It is also observed that the plastic viscosity values reduced as the temperature increased from $113^{\circ} \mathrm{F}$ to $158^{\circ} \mathrm{F}$. The effect of temperature is more pronounced on the plastic viscosity of the HCOBM; the organic base oil in the HCOBM lacks the ability to withstand the temperature effect, and so it reduces when compared to the synthetic oil. The API accepted range of plastic viscosity was reported to be $25-40 \mathrm{cp}$, and 7 and $9 \mathrm{~g}$ SOBM falls within the API range, while that of the HCOBM are not within the range.
This implies that the $7 \mathrm{~g}$ viscosifier is in the best performance range with the concentration of parameter studied.

Figure 5 reveals a decrease in the yield point of the mud with the increase in the temperature from $113^{\circ} \mathrm{F}$ to $158^{\circ} \mathrm{F}$. The yield point is one of the rheological properties that measure the solid suspending capacity of the mud. It can be seen that the yield point values decrease with temperature and also increases with the concentration of the viscosifier. The rate of decrease is high in the HCOBM when compared to the SOBM; this accounts for the higher effect of temperature on the plant oil than on the commercial synthetic oil. The sharp decrease in the plastic viscosity and the yield point of the HCOBM, compared to SOBM, is due to the degradation in the vegetable oil-based mud 
Fig. 6 The 10-s gel strength of synthetic and Hura crepitans oil-based mud at $7 \mathrm{~g}, 9 \mathrm{~g}$ and $113^{\circ} \mathrm{K}, 158^{\circ} \mathrm{K}$ temperatures
20

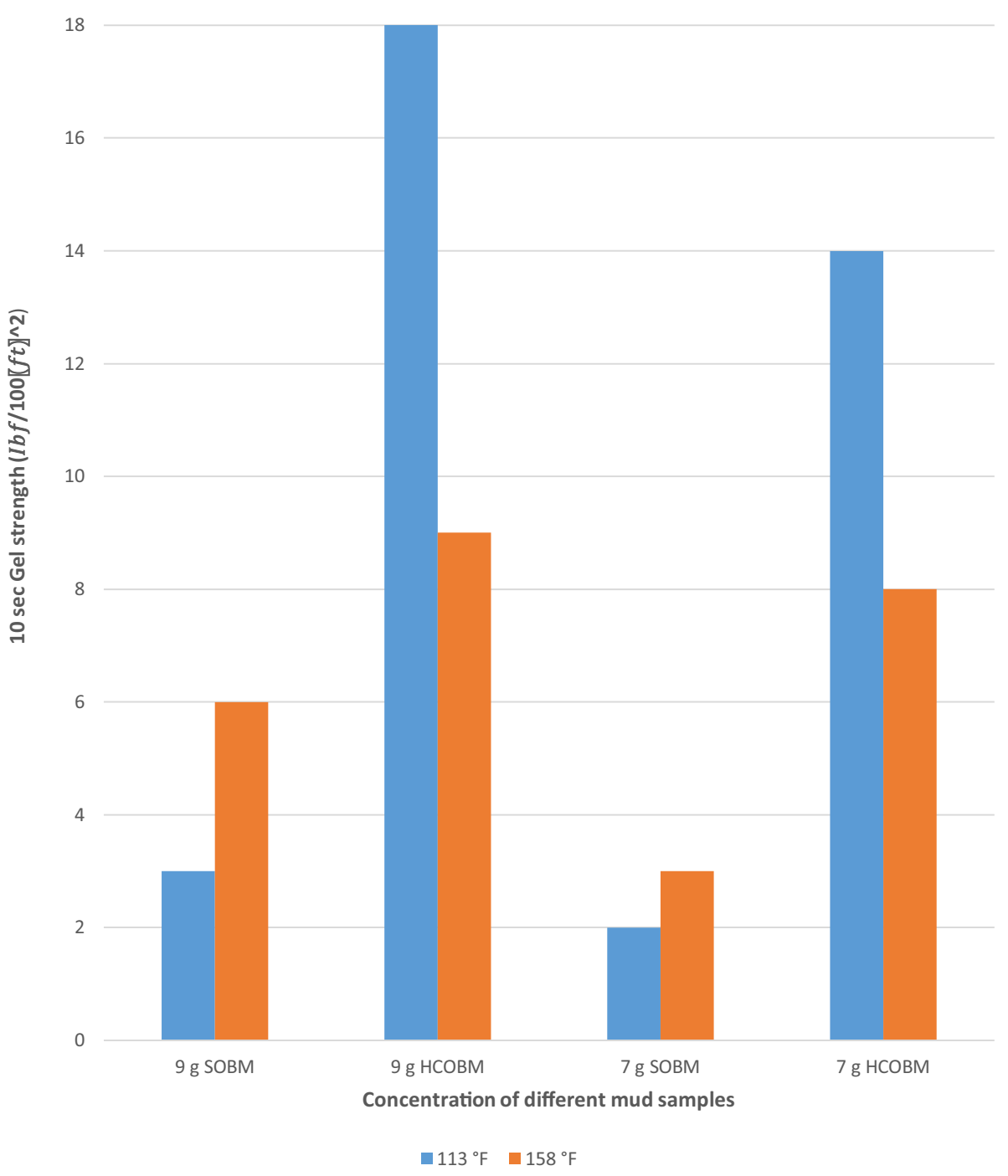

as explained by Olatunde et al. (2012). Fluid with high yield point signifies a non-Newtonian fluid which has the tendency to carry cuttings more to the surface better than fluid of similar density (Amani 2012). Yield point can be lowered by adding deflocculant; this is a thinning agent in reducing viscosity and preventing flocculation, such as water-soluble synthetic polymers, the yield point can also be increased by adding flocculant such as the high-molecular-weight polymers, and this helps in agglomerating mud. The yield point-accepted API range was reported to be $15-45 \mathrm{Ib} / \mathrm{ft}^{2}$. The $7 \mathrm{~g}$ is perfectly within the API range, while the $9 \mathrm{~g}$ is closely within. Hence, the $7 \mathrm{~g}$ shows better performance since it is perfectly within the range. iii. Effect of temperature and the viscosifier on the gel strength

Figures 6 and 7 show the effect of temperature and the viscosifier on the mud samples for 10-s and 10-min gel strength, respectively. From the 10-min and 10-s gel strength values above, the values for HCOBM are higher than those for the SOBM. The gel strength values increase with the increase in the concentration of the viscosifier. Drilling mud with high-and-increasing gel strength is not efficient as it becomes difficult to initiate the movement of the fluid after a break in the drilling operation (Tehrani 2007); this implies that the plant base mud would require more pump pressure 
Fig. 7 The 10-min gel strength of synthetic and Hura crepitans oil-based mud at $7 \mathrm{~g}, 9 \mathrm{~g}$ and

$113^{\circ} \mathrm{K}, 158^{\circ} \mathrm{K}$ temperatures
25

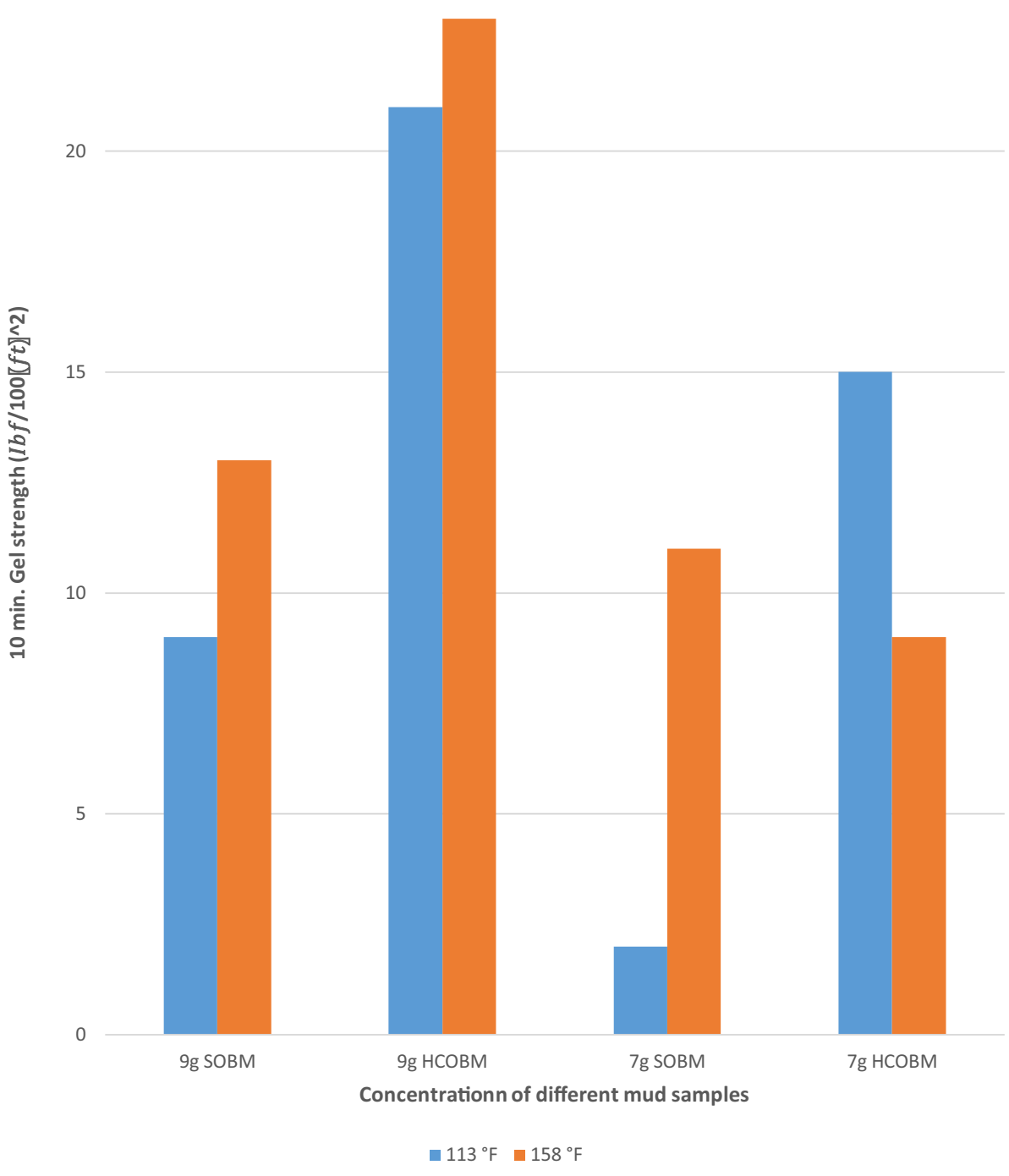

and cost than the SOBM to initiate the flow due to the high gel strength values. Hence, high cost is required in the flow of the vegetable oil-based mud. The 7 and $9 \mathrm{~g}$ viscosifier of the shows a better performance in the 10-s and 10-min gel strength. This is because the gel strength values were within the API accepted range of $8-20 \mathrm{Ib} / 100 \mathrm{ft}^{2}$ for the 10 -s gel strength, and $8-30 \mathrm{Ib} / 100 \mathrm{ft}^{2}$ for 10 -min gel strength.

\section{Aging effect on the rheological properties of synthetic and Hura crepitans oil-based mud}

Mud samples of 7 and $9 \mathrm{~g}$ were aged, and their rheological properties were determined. The shear stress-shear rate was measured after hot rolling (AHR) and compared to the values obtained before hot rolling (BHR). The mud was cooled and rheological property measured at $158^{\circ} \mathrm{F}$ and $113{ }^{\circ} \mathrm{F}$.

i. Aging Effect on the shear stress-shear rate of synthetic and Hura crepitans oil-based mud

Figure 8 shows the shear stress-shear rate plot for synthetic oil-based mud; an increase in the shear stress for the $7 \mathrm{~g}$ and $9 \mathrm{~g}$ SOBM was discovered after hot rolling, with the increase in the yield. This increase signifies that the SOBM was able to retain its properties after aging, and the properties did not deteriorate when the mud was hot-rolled under the effect of temperature. The increase in the shear stress profile is also as a result of the yielding effect of the 
Fig. 8 The stress-shear rate of aged synthetic oil-based mud at $7 \mathrm{~g}, 9 \mathrm{~g}$ viscosifiers and temperature of $158^{\circ} \mathrm{F}$

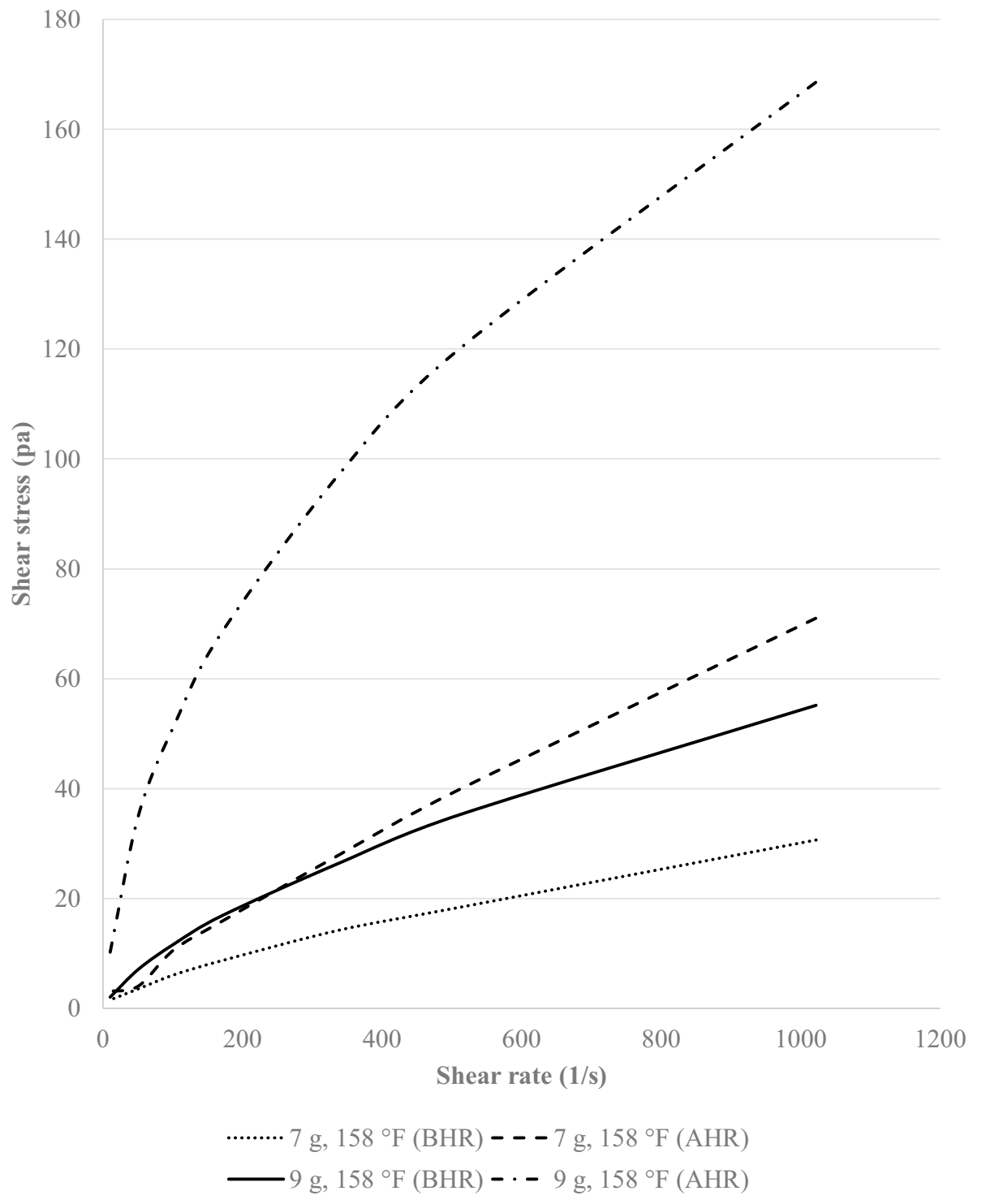

viscosifier under the high-temperature aging conditions; the mud displays a shear thickening effect due to the interaction of the internal structures under aging. The increase in shear stress was due to the sensitive nature of the mud to temperature, ability to withstand heat and retain mud properties, and thickening effect. It is also discovered that the shear stress decreases with the increase in the temperature.

A decrease in the shear stress after hot rolling was observed in the shear stress-shear rate plot of Hura crepitans oil-based mud (Fig. 9), unlike that of synthetic oilbased mud with increase in shear stress after hot rolling.
The decrease in the shear stress-shear rate of $7 \mathrm{~g}$ and $9 \mathrm{~g}$ viscosifier is due to the degradation of the organic component of the HCOBM, causing weakening and breaking down of the internal structures. The HCOBM is dominantly composed of organic plant-based oil, and so broke down under the downhole temperature effect. The mud shear thinning effect was not visible for the plant oil as the shear stress increased more linearly. The viscous flow curves exhibited more of the Newtonian flow behavior over a wide range of shear rate due to the linearity of the plot. 
Fig. 9 The shear stress-shear rate of aged Hura crepitans oilbased mud at $7 \mathrm{~g}, 9 \mathrm{~g}$ viscosifier and temperature of $158^{\circ} \mathrm{F}$

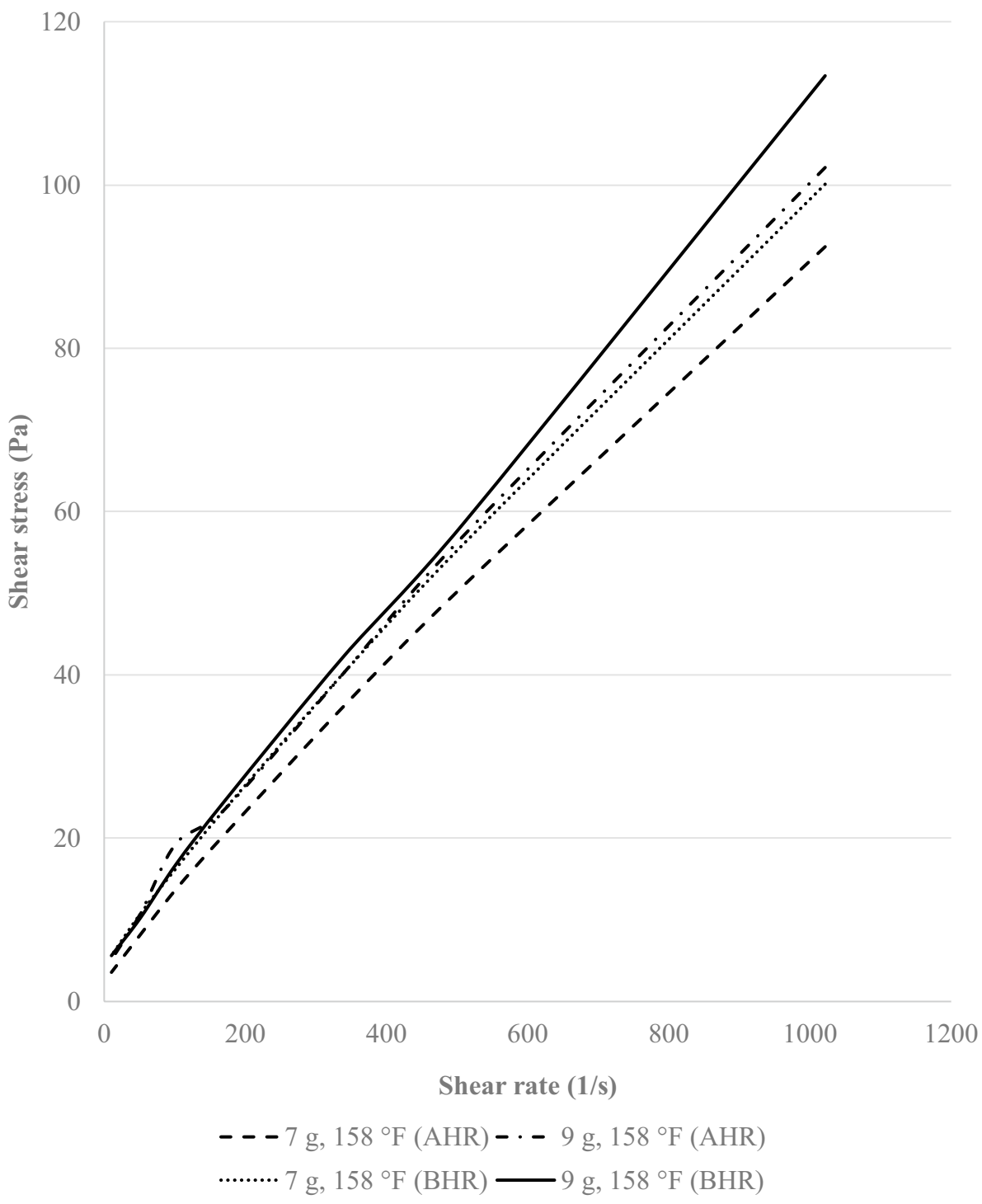

The varying performances of SOBM and HCOBM are also dependent on the type of base oil used and not the linking up and breaking down of the internal molecules. Organic Hura crepitans base oil was used for the HCOBM, while synthetic oil from petroleum source was used for the SOBM. There are possibilities of mud also forming complex networks as observed in the work of Amani (2012) and Ibeh (2007). High shear stress can cause a change in the performance and instability in the mud.

ii. Aging Effect on the plastic viscosity, yield point, and gel strength of the synthetic and Hura crepitans oilbased mud

The plastic viscosity values of the mud samples are shown in Fig. 10; it steadily reduces with temperature and increases with the concentration of the viscosifier. The plastic viscosity value of the 7 and $9 \mathrm{~g} \mathrm{SOBM}$ increased after hot rolling. The increases from this mud sample are accounted for the ability of mud to retain their properties without degradation, and also the yielding effect of the viscosifier. When the mud was subjected to aging, the mud exhibits temperature thinning as a result of the flocculation of the mud particles and further thickening of the mud known as thermal gelation. The decrease in the plastic viscosity values for the HCOBM is as a result of the breaking down of the internal structures. This is due to the thermal instability of plant oil and also thinning effect on the HCOBM due to temperature.

The yield point of the synthetic and Hura crepitans oilbased mud is shown in Fig. 11; the yield values generally increased for SOBM and decreased for the HCOBM after 
Fig. 10 Aging effect on the plastic viscosity synthetic and Hura crepitans oil-based mud at $7 \mathrm{~g}, 9 \mathrm{~g}$ viscosifiers and $113^{\circ} \mathrm{K}$,

$158^{\circ} \mathrm{K}$ temperatures
160

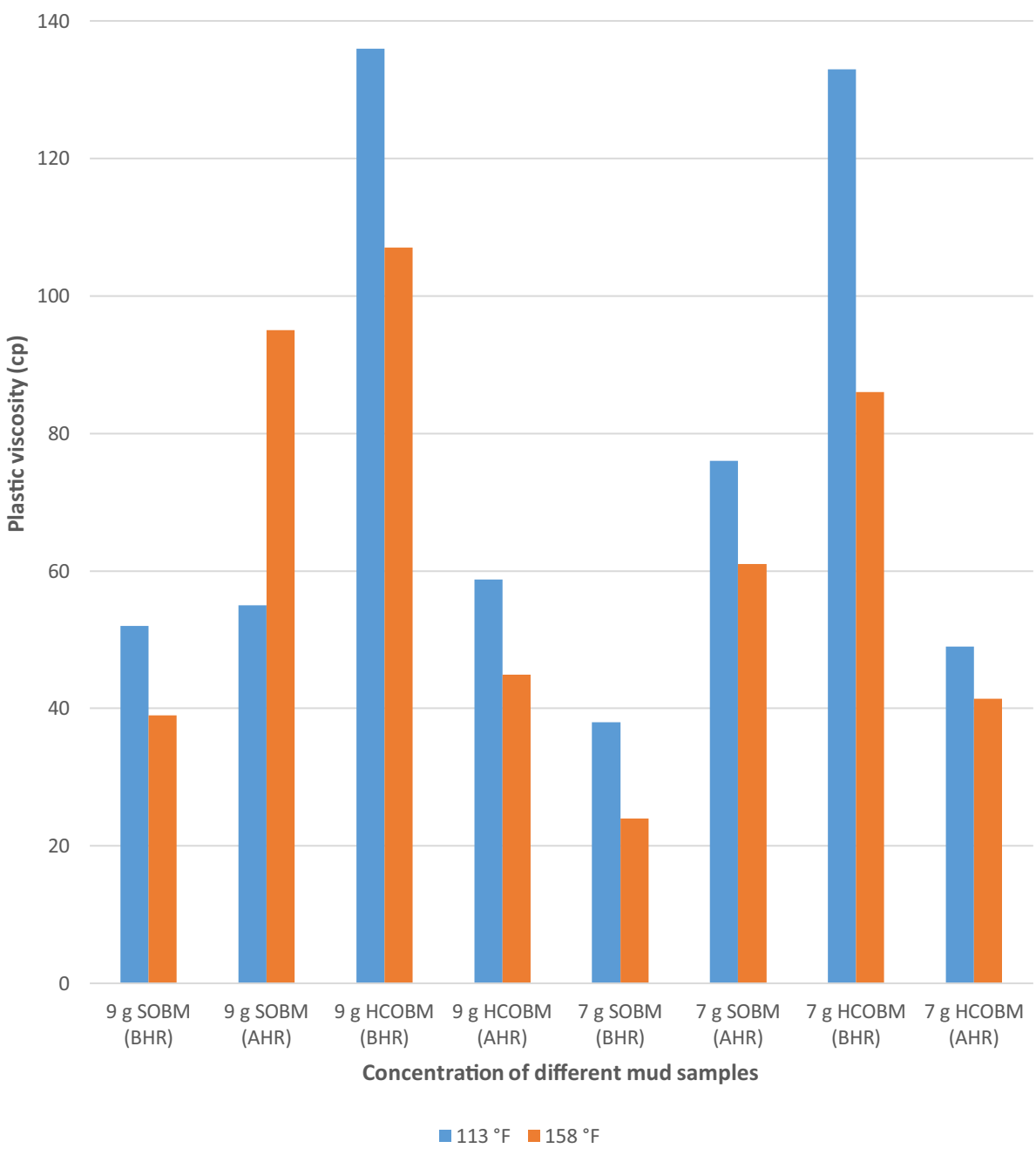

the hot rolling process. The possible cause of the decrease is as a result of mud thinning that occurs due to deflocculation of the particles in the mud, and increase as a result of mud thickening, also known as thermal gelation.

Figure 12 shows that the 10 -s gel strength generally decreases as temperature increases; the gel strength values were not consistent under the downhole aging temperature of the mud. The gel strength for SOBM increases after hot rolling and decreases for the HCOBM.

Figure 13 shows that the 10-min gel strength generally decreases as temperature increases; the gel strength values were not consistent under the downhole aging temperature of the mud. The gel strength for SOBM increases after hot rolling and decreases for the HCOBM.

\section{Rheological models analysis for synthetic and Hura crepitans oil-based mud}

Figure 14 shows the plot of the measured and predicted shear stress-shear rate using Herschel-Bulkley, Casson, hyperbolic, and Sisco rheological model, in describing the experimental data of the SOBM. Figure 14a shows the shear stress-shear rate plot of SOBM with $7 \mathrm{~g}$ viscosifier at $158^{\circ} \mathrm{K}$. Figure $14 \mathrm{~b}$ shows the shear stress-shear rate plot of SOBM with $9 \mathrm{~g}$ viscosifier at $158^{\circ} \mathrm{K}$. Figure $14 \mathrm{c}$ shows the shear stress-shear rate plot of aged SOBM with $7 \mathrm{~g}$ viscosifier at $158^{\circ} \mathrm{K}$, and Fig. $14 \mathrm{~d}$ shows the shear stress-shear rate plot of aged SOBM with $9 \mathrm{~g}$ viscosifier at $158^{\circ} \mathrm{K}$ (Fig. 15). 
Fig. 11 Aging effect on the yield point of synthetic and Hura crepitans oil-based mud at $7 \mathrm{~g}, 9 \mathrm{~g}$ viscosifiers and $113^{\circ} \mathrm{K}$,

$158^{\circ} \mathrm{K}$ temperatures
250

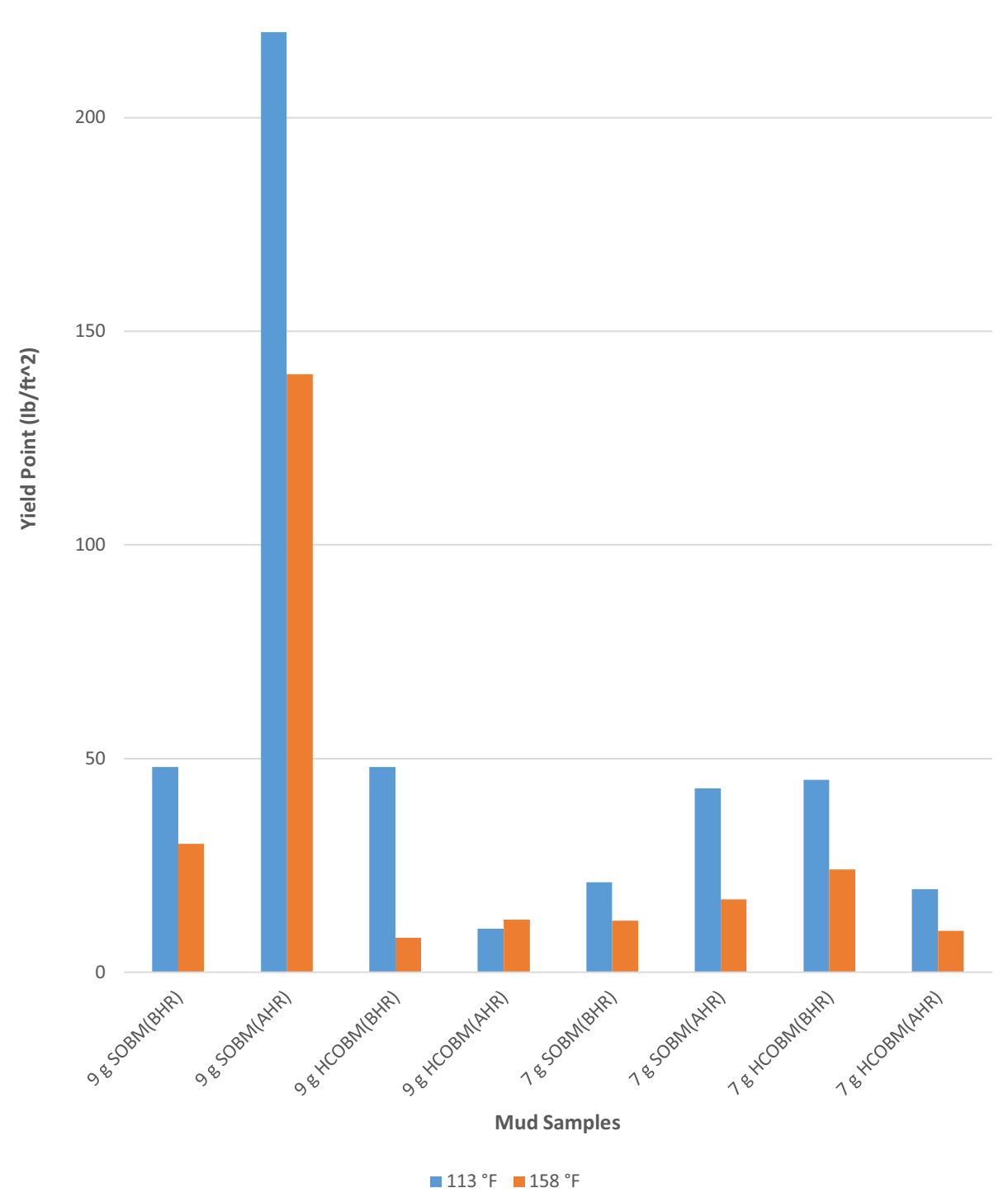

\section{Comparison between the rheological models}

The various rheological models used in describing the experimental data were evaluated using the statistical analysis of the $R^{2}$, RMSE values, and the fitted plots. The $R^{2}$ and RMSE values are summarized in Tables 5, 6, 7, 8, 9, 10, 11 and 12. Tables 5 and 6 show that the Herschel-Bulkley coefficient of determination, $R^{2}$, accounted for $99.9 \%$ to $100 \%$ of the variance between the experimental data points and the fitted regression model. The 7 and $9 \mathrm{~g}$ viscosifier of SOBM and HCOBM had $100 \%$ of data points accounted for; this is reduced when the mud was hot-rolled. $100 \%$ of the data point was also accounted for in the 9-g-aged SOBM and 7-g-aged HCOBM. The negative yield stress values in Tables 5 and 6 are a demonstration of the viscoplasticity, where the fluid behaves as a solid in the phase transition. Hence, it goes out of the viscoelastic range since solid cannot be measured in a flow. Tables 7 and 8 show that the hyperbolic model accounted for $99.7 \%$ to $100 \%$ of the variance. Tables 9 and 10 show that the Sisco model accounted for $99.9 \%$ to $100 \%$ of the variance. Tables 11 and 12 show that the Casson model accounted for $98.6 \%$ to $100 \%$. The Herschel-Bulkley and Sisco models predict the experimental data for the HCOBM using the fitted plots, $R^{2}$ and RMSE 
Fig. 12 Aging effect on the 10-s gel strength of synthetic and Hura crepitans oil-based mud at $7 \mathrm{~g}, 9 \mathrm{~g}$ viscosifiers and $113^{\circ} \mathrm{K}$,

$158^{\circ} \mathrm{K}$ temperatures

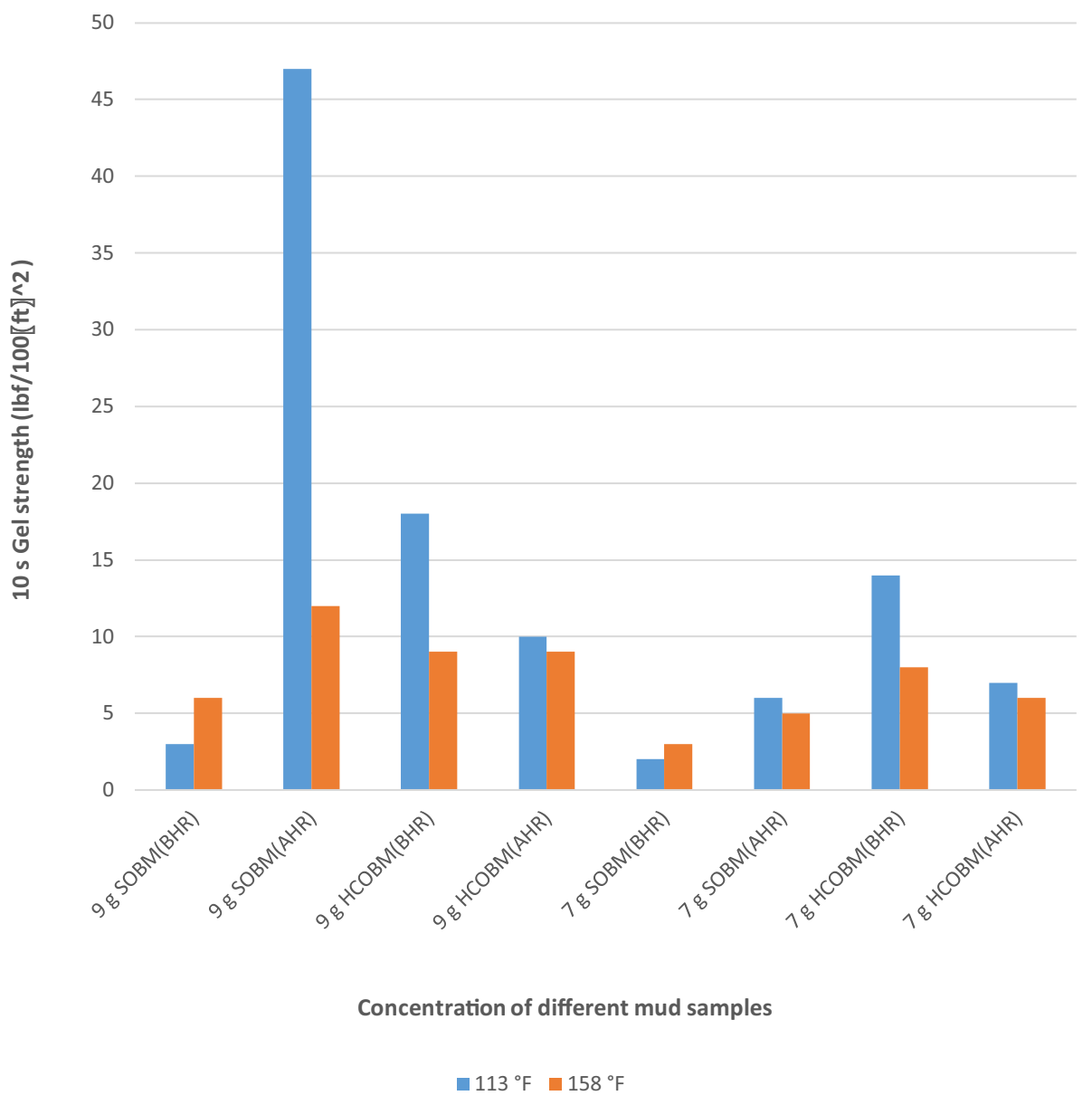

values. In the overall estimation of the RMSE values, $R^{2}$ values, and the fitted plots analysis, the Herschel-Bulkley and the Sisco model had a much better description in predicting the experimental data for the mud samples.

\section{Conclusion(s)}

Rheological properties are one of the most important properties to look out for in drilling fluids, and they must be continuously controlled during any drilling operation; this is attained by chemical modification or the use of appropriate additives.

- Carbogel is a good viscosifier as it increases the rheological properties of the SOBM and the HCOBM

- The rheological properties of the SOBM and HCOBM are both affected by temperature. The rheology profiles show that with temperature increase, the plastic viscosity, yield point, and gel strength decrease.
- The plastic viscosity profile of the mud types increased with the increase in the viscosifier, the profile for HCOBM is higher than that for the SOBM, and this could be as a result of the high viscous Hura crepitans oil exceeding that of the synthetic oil.

- The yield point values of the SOBM are higher than those of the Hura crepitans; higher yield point values are obtained when the viscosifier increased from $7 \mathrm{~g}$ to $9 \mathrm{~g}$ for all mud types. The yield point values after aging for $16 \mathrm{~h}$ at $240{ }^{\circ} \mathrm{F}$ increased for the synthetic oil-based mud and reduced for the pseudo-oil-based formulated with Hura crepitans oil as the base fluid.

- The rheological properties profile of SOBM increased after undergoing aging, and this signifies the ability of the mud to retain its properties after hot rolling. The reverse is the case for the plant oil-based mud.

- The aging effect on the mud samples reveals that the SOBM performs better than the HCOBM, implying that temperature affects the mud with plant oil more than the mud with the synthetic oil. 
Fig. 13 Aging effect on the 10-min gel strength of synthetic and Hura crepitans oil-based mud at $7 \mathrm{~g}, 9 \mathrm{~g}$ viscosifier and $113^{\circ} \mathrm{K}, 158^{\circ} \mathrm{K}$ temperatures
Fig. 14 Measured and predicted shear stress-shear rate of the synthetic oil-based mud

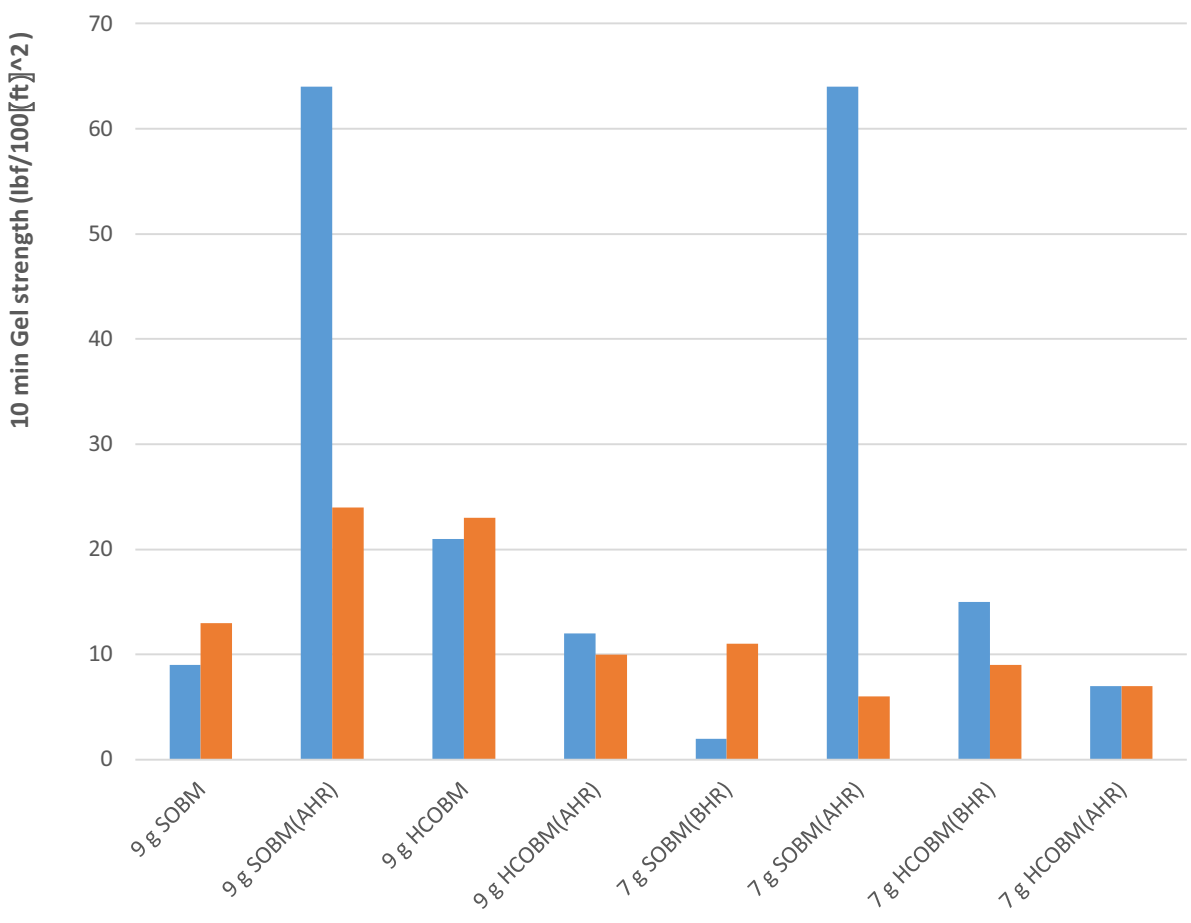

Concentration of different mud samples

$-113^{\circ} \mathrm{F} \quad 158^{\circ} \mathrm{F}$

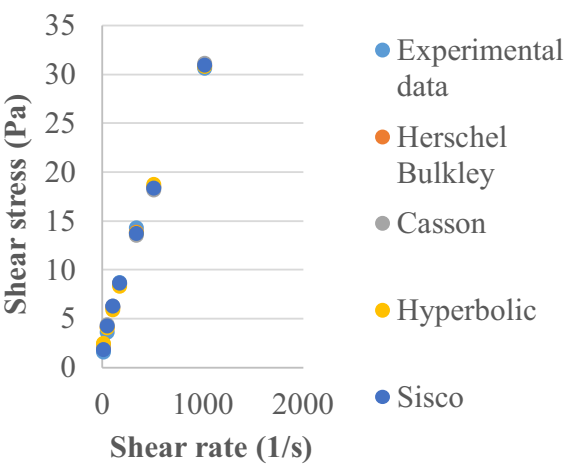

a Synthetic oil-based mud $7 \mathrm{~g}, 158 \quad{ }^{\circ} \mathrm{F}$

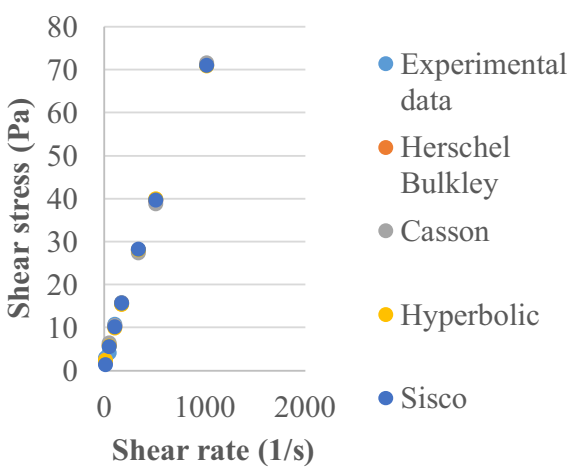

c Aged synthetic oil-based mud 7g, $158 \quad{ }^{\circ} \mathrm{F}$

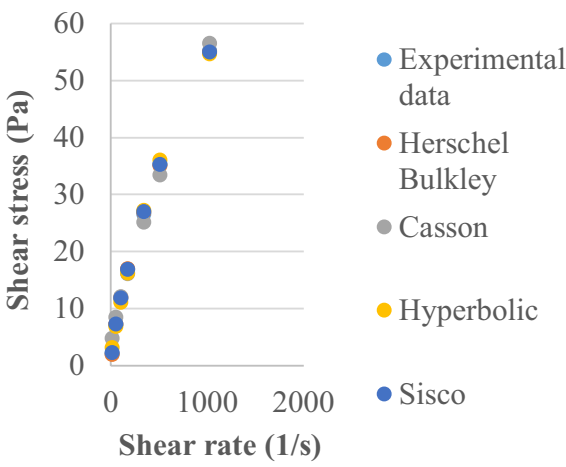

b Synthetic oil-based mud $9 \mathrm{~g}, 158{ }^{\circ} \mathrm{F}$

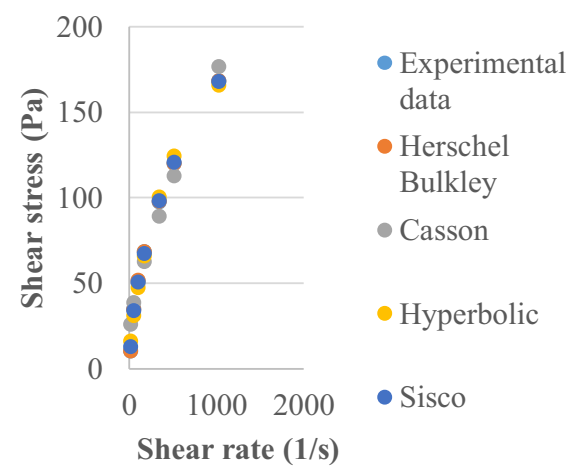

d Aged synthetic oil-based mud 9g, $158 \quad{ }^{\circ} \mathrm{F}$ 
Fig. 15 Measured and predicted shear stress-shear rate of Hura crepitans oil-based mud
Table 5 Herschel-Bulkley model parameters for synthetic and Hura crepitans oil-based mud

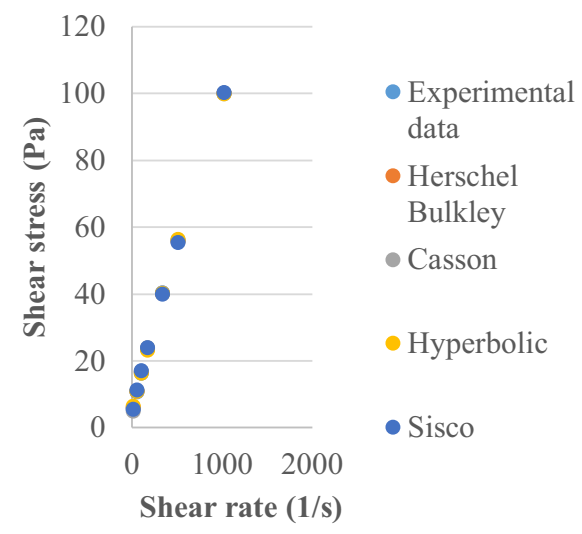

a Hura crepitans oil-based mud $7 \mathrm{~g}, 158 \quad{ }^{\circ} \mathrm{F}$

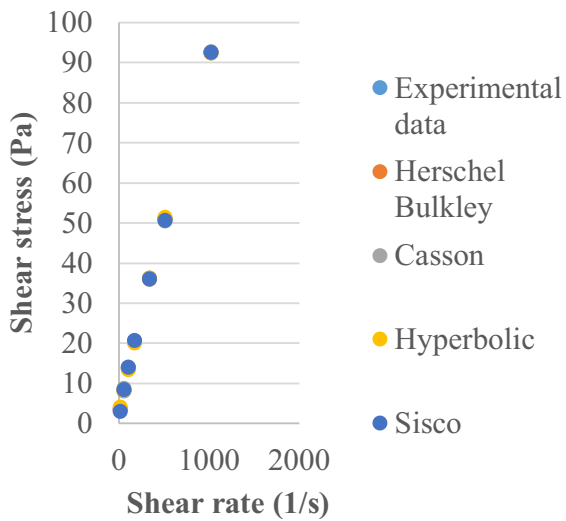

c Aged Hura crepitans oil-based mud 7g, $158{ }^{\circ} \mathrm{F}$

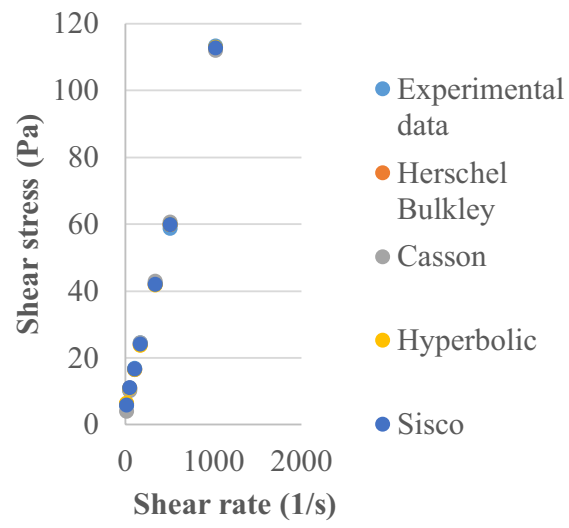

b Hura crepitans oil-based mud $9 \mathrm{~g}, 158{ }^{\circ} \mathrm{F}$

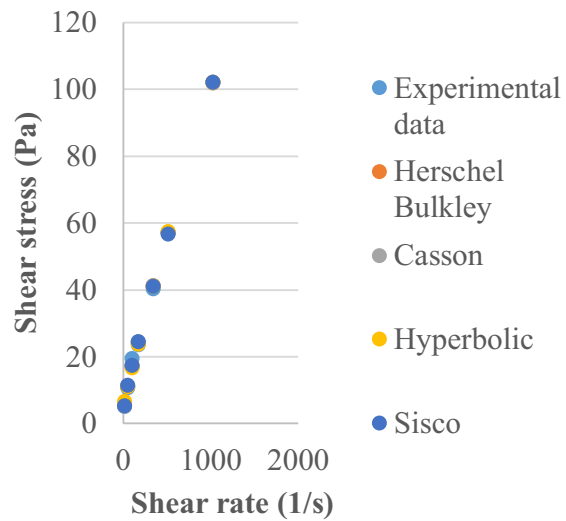

d Aged Hura crepitans oil-based mud 9g, $158{ }^{\circ} \mathrm{F}$

\begin{tabular}{llrllll}
\hline Mud type & $\begin{array}{l}\text { Carbogel vis- } \\
\text { cosifier }(\mathrm{g})\end{array}$ & \multicolumn{6}{l}{ Herschel-Bulkley rheological model } \\
\cline { 3 - 6 } & & $\boldsymbol{\tau}_{01}(\mathrm{~Pa})$ & $K_{1}\left[(\mathrm{~Pa}) s^{n}\right]$ & $n$ & RMSE $(\mathrm{Pa})$ & $R^{2}$ \\
\hline SOBM & 7 & 1.240 & 0.13227 & 0.781 & 0.365 & 1.000 \\
& 9 & -1.129 & 0.69894 & 0.633 & 0.180 & 1.000 \\
HCOBM & 7 & 4.385 & 0.19276 & 0.896 & 0.368 & 1.000 \\
& 9 & 4.974 & 0.12794 & 0.972 & 0.917 & 1.000 \\
\hline
\end{tabular}

Table 6 Herschel-Bulkley model parameters for aged SOBM and aged HCOBM

\begin{tabular}{llrllll}
\hline Mud type & $\begin{array}{l}\text { Carbogel vis- } \\
\text { cosifier }(\mathrm{g})\end{array}$ & \multicolumn{2}{l}{ Herschel-Bulkley rheological model } \\
\cline { 3 - 7 } & & \multicolumn{1}{l}{$\tau_{01}(\mathrm{~Pa})$} & \multicolumn{1}{l}{$K_{1}\left[(\mathrm{~Pa}) s^{n}\right]$} & \multicolumn{1}{l}{$n$} & $\mathrm{RMSE}(\mathrm{Pa})$ & $R^{2}$ \\
\hline Aged SOBM & 7 & 0.585 & 0.18280 & 0.860 & 1.131 & 0.999 \\
& 9 & -12.161 & 7.94320 & 0.451 & 0.397 & 1.000 \\
Aged HCOBM & 7 & 1.953 & 0.19697 & 0.885 & 0.111 & 1.000 \\
& 9 & 4.223 & 0.21111 & 0.886 & 1.426 & 0.999 \\
\hline
\end{tabular}

- The Herschel-Bulkley, hyperbolic, and Sisco models closely predict the experimental shear stress-shear rate of the mud base on the $R^{2}$ values. Herschel-Bulkley is pre- ferred among all bases on the $R^{2}$ values, RMSE values, and the fitted plots. 
Table 7 Hyperbolic model parameters for synthetic and Hura crepitans oil-based mud

Table 8 Hyperbolic model parameters for aged SOBM and aged HCOBM

Table 9 Sisco model parameters for synthetic and Hura crepitans oil-based mud

Table 10 Sisco model parameters for aged SOBM and aged HCOBM

\begin{tabular}{lllllll}
\hline Mud type & $\begin{array}{l}\text { Carbogel vis- } \\
\text { cosifier }(\mathrm{g})\end{array}$ & \multicolumn{2}{l}{ Hyperbolic rheological model } \\
\cline { 3 - 6 } & & $\tau_{02}(\mathrm{~Pa})$ & $A[(\mathrm{~Pa}) s]^{-1}$ & & RMSE $(\mathrm{Pa})$ & $R^{2}$ \\
\hline SOBM & 7 & 2.087 & 25.89 & 0.009 & 0.584 & 0.999 \\
& 9 & 2.215 & 10.71 & 0.009 & 1.034 & 0.999 \\
HCOBM & 7 & 5.361 & 9.28 & 0.001 & 0.505 & 1.000 \\
& 9 & 5.379 & 9.25 & 0.0003 & 0.994 & 1.000 \\
\hline
\end{tabular}

\begin{tabular}{llccccc}
\hline Mud type & $\begin{array}{l}\text { Carbogel vis- } \\
\text { cosifier }(\mathrm{g})\end{array}$ & \multicolumn{5}{l}{ Hyperbolic rheological model } \\
\cline { 3 - 6 } & & $\tau_{02}(\mathrm{~Pa})$ & $A[(\mathrm{~Pa}) s]^{-1}$ & $B[\mathrm{~Pa}]^{-1}$ & RMSE $(\mathrm{Pa})$ & $R^{2}$ \\
\hline Aged SOBM & 7 & 1.511 & 11.80 & 0.003 & 1.027 & 0.999 \\
& 9 & 12.089 & 2.46 & 0.004 & 5.181 & 0.997 \\
Aged HCOBM & 7 & 2.998 & 9.667 & 0.002 & 0.410 & 1.000 \\
& 9 & 5.514 & 9.102 & 0.002 & 1.674 & 0.999. \\
\hline
\end{tabular}

\begin{tabular}{llcllll}
\hline Mud type & $\begin{array}{l}\text { Carbogel vis- } \\
\text { cosifier }(\mathrm{g})\end{array}$ & \multicolumn{2}{l}{ Sisco rheological model } \\
\cline { 3 - 7 } & & $K_{2}\left[(\mathrm{~Pa}) s^{-1}\right]$ & $K_{3}\left[(\mathrm{~Pa}) s^{m}\right]$ & $m$ & RMSE $(\mathrm{Pa})$ & $R^{2}$ \\
\hline SOBM & 7 & 0.0190 & 0.615 & 0.423 & 0.344 & 1.000 \\
& 9 & -0.0318 & 0.438 & 0.764 & 0.253 & 1.000 \\
HCOBM & 7 & 0.0829 & 2.461 & 0.267 & 0.674 & 1.000 \\
& 9 & 0.1026 & 3.730 & 0.109 & 0.845 & 1.000 \\
\hline
\end{tabular}

\begin{tabular}{lllllll}
\hline Mud type & $\begin{array}{l}\text { Carbogel vis- } \\
\text { cosifier }(\mathrm{g})\end{array}$ & \multicolumn{2}{l}{ Sisco rheological model } \\
\cline { 3 - 7 } & & $K_{2}\left[(\mathrm{~Pa}) s^{-1}\right]$ & $K_{3}\left[(\mathrm{~Pa}) s^{m}\right]$ & $m$ & RMSE(Pa) & $R^{2}$ \\
\hline Aged SOBM & 7 & -0.173 & 0.214 & 0.870 & 1.169 & 0.999 \\
& 9 & -0.080 & 3.237 & 0.627 & 1.757 & 1.000 \\
Aged HCOBM & 7 & 0.071 & 0.771 & 0.468 & 0.419 & 1.000 \\
& 9 & 0.082 & 2.200 & 0.304 & 1.263 & 1.000 \\
\hline
\end{tabular}

Table 11 Casson model parameters for synthetic and Hura crepitans oil-based mud

\begin{tabular}{llllll}
\hline Mud type & $\begin{array}{c}\text { Carbogel } \\
\text { viscosifier }\end{array}$ & \multicolumn{5}{c}{ Casson rheological model } \\
& $\begin{array}{c}\tau_{03}(\mathrm{~Pa}) \\
\text { SOBM }\end{array}$ & 7 & $K_{4}\left[(\mathrm{~Pa}) s^{-1}\right]$ & $\mathrm{RMSE}(\mathrm{Pa})$ & $R^{2}$ \\
& 9 & 1.159 & 0.0199 & 0.399 & 0.999 \\
$\mathrm{HCOBM}$ & 7 & 2.523 & 0.0345 & 1.934 & 0.996 \\
& 9 & 1.872 & 0.0729 & 0.621 & 1.000 \\
& & 1.096 & 0.0890 & 1.401 & 0.999 \\
\hline
\end{tabular}

Open Access This article is distributed under the terms of the Creative Commons Attribution 4.0 International License (http://creativeco mmons.org/licenses/by/4.0/), which permits unrestricted use, distribution, and reproduction in any medium, provided you give appropriate credit to the original author(s) and the source, provide a link to the Creative Commons license, and indicate if changes were made.
Table 12 Casson model parameters for aged SOBM and aged HCOBM

\begin{tabular}{llrlll}
\hline Mud type & $\begin{array}{l}\text { Carbogel } \\
\text { viscosifier } \\
\end{array}$ & \multicolumn{4}{l}{ Casson rheological model } \\
\cline { 3 - 6 } & & $\tau_{03}(\mathrm{~Pa})$ & $K_{4}\left[(\mathrm{~Pa}) s^{-1}\right]$ & $\mathrm{RMSE}(\mathrm{Pa})$ & $R^{2}$ \\
\hline Aged SOBM & 7 & 0.707 & 0.0569 & 1.253 & 0.999 \\
& 9 & 17.613 & 0.0810 & 9.859 & 0.986 \\
Aged & 7 & 1.040 & 0.0726 & 0.410 & 1.000 \\
HCOBM & 9 & 1.957 & 0.0741 & 1.172 & 0.999 \\
\hline
\end{tabular}

\section{References}

Agwu OE, Okon AN, Udoh FD (2015) A comparative study of diesel oil and soybean oil as oil-based drilling mud. J Pet Eng 2015:1-10. https://doi.org/10.1155/2015/828451 
Amani M (2012) The rheological properties of oil-based mud under high pressure and high temperature conditions. Adv Pet Explor Dev 3(2):21-30. https://doi.org/10.3968/j.aped.1925543820 120302.359

Amorin R, Dosunmu A, Amankwah RK (2015a) Economic viability of the use of local pseudo-oils for drilling fluid formulation. Ghana Min J 15(2):81-90

Amorin R, Dosunmu A, Amankwah RK (2015b) Enhancing the stability of local vegetable oils (esters) for high geothermal drilling applications. J Pet Gas Eng 6(8):90-97

Anawe PAL, Efeovbokhan V, Ayoola A, Akpanobong O (2014) Investigating alternatives to diesel in oil based drilling mud formulations used in the oil industry. J Environ Earth Sci 4(14):70-78

Atabani AE, Silitonga AS, Ong HC, Mahlia TMI, Masjuki HH, Badruddin IA, Fayaz H (2013) Non-edible vegetable oils: a critical evaluation of oil extraction, fatty acid compositions, biodiesel production, characteristics, engine performance and emissions production. Renew Sustain Energy Rev 18:211-245

Dardir MM, Hafiz AA (2013) Esteramide as an environmentally friendly synthetic based drilling fluids. J Am Sci 9(6):133-142

Dardir MM, Ibrahime S, Soliman M, Desouky SD, Hafiz AA (2014) Preparation and evaluation of some esteramides as synthetic based drilling fluids. Egypt J Pet 23(1):35-43. https://doi.org/10.1016/j. ejpe.2014.02.006

Dosunmu A, Ogunride J (2010) Development of environmentally friendly oil based mud using palm-oil and groundnut-oil. In: 34th Annual SPE international conference and exhibition. Society of Petroleum Engineers, Calabar, pp 1-9

Fadairo A, Olutola P, Ogunkunle T, Oladepo A (2017) Formulation and evaluation of synthetic drilling mud for low temperature regions. Covenant J Eng Technol 1(1):34-48

Growcock FB, Patel AD (2011) The revolution in non-aqueous drilling fluids, AADE-11-NTCE-33. In AADE national technical conference and exhibition. American Association of Drilling Engineers, Houston, TX, pp 1-8

Haines D, Gerpen JV (2014) Biodiesel and the food vs. fuel debate. https://articles.extension.org/pages/27136/biodiesel-and-the-foodvs-fuel-debate. Retrieved January 13, 1BC

Ibeh CS (2007) Investigation on the effects of ultra-high pressure and temperature on the rheological properties of oil-based drilling fluids. Texas A\&M University, College Station

Li W, Zhao X, Ji Y, Peng H, Li Y, Liu L, Han X (2016) An investigation on environmentally friendly biodiesel-based invert emulsion drilling fluid. J Pet Explor Prod Technol 6(3):505-517. https://doi. org/10.1007/s13202-015-0205-7

Mozaffari S, Tchoukov P, Atias J, Czarnecki J, Nazemifard N (2015) Effect of asphaltene aggregation on rheological properties of diluted athabasca bitumen. Energy Fuels 29:5595-5599

Olatunde AO, Usman MA, Olafadehan OA, Adeosun TA, Ufot OE (2012) Improvement of rheological properties of drilling fluid using locally based materials. Pet Coal 54(1):65-75

Salih N, Salimon J, Yousif E (2011) Synthesis of oleic acid based esters as potential basestock for biolubricant production. Turk J Eng Environ Sci 35(2):115-123

Searchinger T, Heimlich R (2015) Avoiding bioenergy competition for food crops and land. Installment 9 of creating a sustainable food future no. 9, Washington, D.C.

Tehrani A (2007) Behaviour of suspensions and emulsions in drilling fluids. Ann Trans Nord Rheol Soc 15:1-9

Publisher's Note Springer Nature remains neutral with regard to jurisdictional claims in published maps and institutional affiliations. 